\title{
IL5RA wt Allele
}

National Cancer Institute

\section{Source}

National Cancer Institute. IL5RA wt Allele. NCI Thesaurus. Code C51367.

Human IL5RA wild-type allele is located within 3p26-p24 and is approximately $41 \mathrm{~kb}$ in length. This allele, which encodes interleukin-5 receptor subunit alpha protein, is involved in transcriptional mediation and cytokine regulation. 